\title{
SOSIALISASI PENGARUH MOTIVASI TERHADAP PRESTASI MAHASISWA STIE AL-WASHLIYAH SIBOLGA/TAPANULI TENGAH
}

\author{
NELLY AZWARNI SINAGA
}

\begin{abstract}
ABSTRAK
Bangsa Indonesia merupakan bangsa yang besar. Pembangunan yang berlangsung sampai saat ini tidak hanya membangun secara fisik semata, tetapi juga non fisik berupa peningkatan kualitas sumber daya manusia. Dalam persaingan global saat ini, dunia kerja sangat membutuhkan orang yang bisa berfikir untuk maju, cerdas, inovatif dan mampu berkarya dengan semangat tinggi dalam menghadapi kemajuan jaman. Tidak hanya itu, dalam kondisi saat ini peran dari sumber daya manusia sendiri yang mempunyai peran penting. Dalam dunia pendidikan motif mahasiswa dalam belajar dapat berbeda satu sama lain. Adanya perbedaan motivasi tersebut dipengaruhi oleh motivasi yang dibedakan dalam dua bentuk yaitu Motivasi Intrinsik atau Motivasi Intern (Internal Motivation) yaitu motivasi yang muncul dari dalam diri sendiri karena adanya kebutuhan tanpa dipengaruhi oleh sesuatu diluar dirinya, dan Motivasi Ekstrinsik atau Motivasi Ekstern (Eksternal Motivation) yaitu motivasi yang muncul dalam diri seseorang karena adanya pengaruh dari luar seperti guru/dosen, orang tua dan lingkungan sekitarnya. Kegiatan Pengabdian Kepada Masyarakat dalam bentuk Sosialisasi yang dilakukan oleh Salah Satu Dosen STIE Al-Washliyah Sibolga di tempat dimana Dosen tersebut bertugas, hal ini dapat dilihat dalam bentuk hasil kegiatan pada setiap pelaksanaan yang terangkum dalam beberapa tahapan. Kegiatan Pengabdian ini dilakukan sebagai salah satu upaya untuk meningkatkan motivasi bagi Mahasiswa STIE AW Sibolga untuk lebih meningkatkan dalam Prestasi Belajarnya Kegiatan Pengabdian ini dilakukan untuk memberikan pemahaman tentang arti pentingnya dari motivasi sebagai salah satu indikator untuk keberhasil dalam menempuh studi dan menyelesaikan studinya sehingga apa yang dicita citakannya tercapai selesai tepat waktu.
\end{abstract}

Kata Kunci :Prestasi Belajar, Motivasi, Mahasiswa.tepat waktu

\begin{abstract}
The Indonesian nation is a great nation. Development that continues to date not only produces but is not physical. In today's global competition, the world of work is in desperate need of people who can think forward, smart, innovative and able to work with enthusiasm in the face of advancing times. Not only that, in the current condition of human roles. In the world of education motives, students in learning can differ from one another. The existence of motivational things that are influenced by motivation are divided into two forms, namely Intrinsic Motivation or Internal Motivation (Internal Motivation), namely the motivation that comes from within yourself because there is no action and Extrinsic Motivation or External Motivation (External Motivation) which is motivation appear in a person because of outside influences such as teacher/lecturer, parents, and the surrounding environment. Community Service Activities in the form of Community conducted by One Lecturer of STIE Al-Washliyah Sibolga where the Lecturer is, this can be seen in various stages. This devotion activity is carried out as one of the efforts to increase motivation for STIE AW Sibolga students to further improve their learning achievement. This service activity is carried out to provide an understanding of the meaning of one indicator for success in electrical studies and discussion of studies in what the sponsor aspires to complete. on time.
\end{abstract}

Keywords: Learning Achievement, Motivation, Students 


\section{PENDAHULUAN}

Bangsa Indonesia merupakan bangsa yang besar. Pembangunan yang berlangsung sampai saat ini tidak hanya membangun secara fisik semata, tetapi juga non fisik berupa peningkatan kualitas sumber daya manusia. Dalam persaingan global saat ini, dunia kerja sangat membutuhkan orang yang bisa berfikir untuk maju, cerdas, inovatif dan mampu berkarya dengan semangat tinggi dalam menghadapi kemajuan jaman. Tidak hanya itu, dalam kondisi saat ini peran dari sumber daya manusia sendiri yang mempunyai peran penting. Motivasi adalah merupakan perilaku untuk mencapai tujuan yang telah ditentukan.Dalam Ilmu Manajemen , motivasi bukanlah hal yang tabu untuk dibicarakan.Motivasi juga adalah merupakan kekuatan yang mendorong untuk mengarahkan keberhasilan perilaku yang tetap kearah tujuan tertentu. Motivasi bisa berasal dari dalam diri seseorang ataupun dari luar dirinya. Motivasi mempunyai peranan yang strategis dalam aktivitas dari belajar seseorang.Tidak ada seorangpun yang belajar tanpa motivasi. Tidak ada motivasi berarti tidak ada kegiatan belajar. Motivasi berasal dari bahasa Latin "movere" yang berarti dorongan atau menggerakkan. Menurut Desy Anwar (2003) dalam Kamus Lengkap Bahasa Indonesia Terbaru, "Motif adalah sebab-sebab yang menjadi dorongan, tindakan seseorang; dasar pikiran atau pendapat;sesuatu yang jadi pokok". Motivasi merupakan salah satu aspek yang sangat berpengaruh pada diri manusia dalam konteks produktifitas kerja maupun terhadap prestasi seseorang. Seseorang yang memiliki motivasi tinggi akan menunjukkan minat, perhatian, konsentrasi penuh, ketekunan tinggi serta berorientasi pada prestasi tanpa mengenal perasaan bosan, jenuh apalagi menyerah.

H.W. Bernard dalam Bukunya Psychologi Of Learning (1965) mengemukakan bahwa Motivasi adalah proses membangkitkan mengekalkan dan mengawal minat.Menurut Sharifah Alwiah Alsogoff (1986) menguraikan bahwa motivasi sebagai perangsangan tindakan terhadap tujuan tersebut. Secara ringkasnya motivasi merupakan perangsangan yang membangkitkan dan mengekalkan minat seseorang individu kearah mencapai sesuatu matlamat tertentu, termasuk mengubah sikap, minat dan tingkah lakuknya.Ia biasanya diwujudkan kerana keperluan fisiologi atau psikologi yang timbul.

Menurut Woolfolk (1990) motivasi dirujuk kepada satu kuasa dalaman yang membangkit, mengarah dan mengawal minat serta tingkah laku manusia.

Dalam dunia pendidikan motif mahasiswa dalam belajar dapat berbeda satu sama lain. Adanya perbedaan motivasi tersebut dipengahruhi oleh motivasi yang dibedakan dalam dua bentuk yaitu Motivasi Intrinsik atau Motivasi Intern (Internal Motivation) yaitu motivasi yang muncul dari dalam diri sendiri karena adanya kebutuhan tanpa dipengaruhi oleh sesuatu diluar dirinya, dan Motivasi Ekstrinsik atau Motivasi Ekstern (Eksternal Motivation) yaitu motivasi yang muncul dalam diri seseorang karena adanya pengaruh dari luar seperti guru/dosen, orang tua dan lingkungan sekitarnya.

Motivasi dan Belajar adalah merupakan dua hal yang saling 
mempengaruhi.Dalam proses belajar, motivasi sangat diperlukan. Sebagaimana yang dikemukakan oleh Hamalik (2011:161) motivasi sangat menentukan tingkat berhasil atau gagalnya perbuatan belajar mahasiswa.Belajar tanpa adanya motivasi kiranya akan sangat sulit untuk berhasil. Hal ini disebabkan karena seseorang yang tidak mempunyai motivasi dalam belajar, tidak akan mungkin melakukan aktivitas belajar.Hal ini adalah merupakan pertanda bahwa sesuatu yang akan dikerjakan itu tidak menyentuh kebutuhannya.Segala sesuatu yang menarik minat orang lain belum tentu menarik minat yang lain selama sesuatu itu tidak bersentuhan dengan kebutuhannya (Djamarah,2008:148).

\section{METODE PELAKSANAAN}

Metode Kegiatan ini berupa Sosialisasi Tentang Pengaruh Motivasi Dapat Meningkatkan Kemampuan Prestasi Mahasiswa Dalam Belajar Dan Dalam Menyelesaikan Studinya untuk tepat waktu.Setelah diberi pengetahuan mengenai dasar-dasar Teori Motivasi dapat diimplementasikan dalam kehidupan sehari-hari.

Adapan Tahapan Kegiatan Sosialisasi ini antara lain :

1.Tahap Persiapan.

Tahap persiapan meliputi antara lain : a.Meninjau Lokasi

b.Pemantapan Dan Penentuan Lokasi dan Penentuan Lokasi Sasaran Sosialisasi.Serta penunjang lainnya seperti : Surat-menyurat, Spanduk, Daftar Hadir, Sertifikat, Konsumsi dll.

\section{Tahap Pelaksanaan}

Pelaksanaan kegiatan dimulai dengan Seremonial Pembukaan Dan Sambutan yang berkenaan dengan tujuan pelaksanaan kegiatan yaitu Peningkatan Motivasi kepada Mahasiswa sehingga diharapkan kelak dapat berkontribusi untuk Peningkatan Prestasinya.

Adapun Metode Sosialisasi yang dilakukan antara lain :

a.Metode Ceramah Interaktif

Hal ini dilakukan antara Pemateri Dengan mahasiswa yang mengikuti Sosialisasi

b.Metode Tanya Jawab

Metode ini dilakukan kepada Mahasiswa untuk lebih memahamkan kepada terhadap materi yang disosialisasikan.

c.Metode Menampilkan Vidio

Dalam Metode ini akan ditampilkan kepada Mahasiswa vidio-vidio yang berkaitan dengan motivasi bagaimana dalam bentuk gambar gambar sehingga Mahasiswa termotivasi untuk menimplementasikan dalam kehidupan sehari-hari.

\section{HASIL}

Kegiatan Pengabdian Kepada Masyarakat dalam bentuk Sosialisasi yang dilakukan oleh Salah Satu Dosen STIE Al-Washliyah Sibolga di tempat dimana Dosen tersebut bertugas, hal ini dapat dilihat dalam bentuk hasil kegiatan pada setiap pelaksanaan yang terangkum dalam beberapa tahapan.

a. Melaksanakan Kegiatan

Kegiatan Pengabdian ini dilakukan sebagai salah satu upaya untuk meningkatkan motivasi bagi Mahasiswa STIE AW Sibolga 
untuk lebih meningkatkan dalam Prestasi Belajarnya

\section{b. Observasi}

Kegiatan observasi ini dilakukan untuk mengetahui seberapa jauh pengetahuan dan pemahaman dari mahasiswa tentang arti pentingnya dari motivasi sebagai salah satu indikator untuk keberhasil dalam menempuh studi dan menyelesaikan studinya sehingga apa yang dicita ctakannya tercapai selesai tepat waktu.

Didalam menjalankan kegiatan Sosialisasi ini tentunya ada mengalami beberapa kendala, salah satunya adanya mengingat waktu yang dilakukan untuk melaksanakan kegiatan ini sangat terbatas sehingga apa yang menjadi target untuk lebih memahamkan kegiatan ini masih dirasakan kurang,sehingga lain waktu perlu dilaksanakan kegiatan ini untuk lebih membangkitkan semangat dari Peserta Sosialisasi.

Namun demikian dirasakan bahwa kegiatan ini sangat bermanfaat dilaksanakan mengingat Peserta yang mengikuti Sosialisasi ini berasal Dari Mahasiswa Semester Awal yang masih semangat dan penuh antuasias dengan adanya kegiatan ini akan lebih memahamkan lagi dalam kegiatan Perkuliahan yang sedang dijalaninya.

Berdasarkan observasi yang dikemukakan ,untuk mengatasi kendala yang terjadi terhadap kegiatan sosialisasi ini .Untuk kedepannya perlu dilakukan kegiatan sosialisasi ini perlu penambahan waktu untuk lebih intens sehingga lebih memahamkan kepada Mahasiswa. Evaluasi yang dilakukan bertujuan untuk dapat mengatasi kendala dari waktu tersebut pada kegiatan Sosialisasi tentang
Motivasi yang dilakukan terhadap Mahasiswa STIE AW Sibolga.

\section{PEMBAHASAN}

STIE $\begin{array}{ccc}\text { Kegiatan } & \text { Pengabdian } & \text { pada } \\ \text { AW } & \text { Sibolga } & \text { telah }\end{array}$ terselenggaranya dan berjalan dengan baik. Hal ini dapat dilihat dari antusias dari Mahasasiswa-mahasiswa untuk mengikuti kegiatan Sosialisasi ini. Motivasi mahasiswa yang besar untuk mencapai suatu tujuan, berarti mahasiswa tersebut tidak akan memikirkan factor lain yang kemungkinan menghambat tercapainya tujuan tersebut. Mahasiswa akan lebih terfokus untuk tercapainya tujuan dan akan menerjang semua rintangan untuk tercapainya tujuan. Bila tujuan utama mahsiswa untuk meningkatkan prestasi belajar, maka semua jalan untuk meningkatkan prestasi akan dia tempuh, asalkan dia mampu mendapat prestasi belajar yang tinggi.

Menurut Sardiman ,(1986: 75)

Motivasi belajar adalah keseluruhan daya penggerak dalam diri Mahasiswa , yang menjamin kelangsungan dari kegiatan belajar dan memberikan arah pada kegiatan belajar, sehingga tujuan yang dikehendaki oleh subjek belajar itu dapat tercapai. Sedangkan Menurut Winkel (2003) dan Puspitasari (2012) Motivasi belajar adalah segala usaha di dalam diri sendiri yang menimbulkan kegiatan belajar, dan menjamin kelangsungan dari kegiatan belajar sehingga tujuan yang dikehendaki tercapai. Motivasi belajar merupakan faktor psikis yang bersifat non intelektual dan berperan dalam hal menumbuhkan semangat belajar untuk individu.

Banyak teori motivasi yang dikemukakan oleh para ahli antara lain Teori Motivasi Abraham Maslow 
(1943 - 1970) mengemukakan bahwa pada dasarnya semua manusia memiliki kebutuhan pokok. Ia menunjukkan 5 tingkatan yang berbentuk piramid, orang akan memulai dorongan dari tingkatan terbawah. Lima tingkatan kebituhan itu dikenal dengan sebutan Hirarkhi Kebutuhan Maslow , yang dimulai dari kebutuhan biologis dasar sampai motif psikologis yang lebih kompleks, Kebutuhan pada suatu peringkat paling tidak harus terpenuhi sebagian sebelum kebutuhan pada peringkat berikutnya menjadi penentu tindakan yang penting.

Kebutuhan-kebutuhan tersebut antara lain :

-Kebutuhan Fisiologis (rasa lapar, rasa haus, dan sebagainya.)

-Kebutuhan rasa aman (merasa aman dan terlindung, jauh dari bahaya)

-Kebutuhan akan rasa cinta dan rasa memiliki (berafiliasi dengan orang lain, diterima,memiliki).

-Kebutuhan akan penghargaan (berprestasi, berkompetensi, dan mendapatkan dukungan serta pengakuan)

-Kebutuhan aktualisasi diri (kebutuhan kognitif, mengetahui, memahami dan menjelajahi, kebutuhan estetik, keserasian, keteraturan, dan keindahan, kebutuhan aktualisasi diri untuk mendapatkan kepuasan diri dan menyadari potensinya.

Motivasi untuk meraih prestasi belajar merupakan bagian teori yang dikemukakan oleh Abraham Maslow. Dengan Motivasi akan mendorong mahasiswa tersebut untuk bekerja lebih keras, lebih semangat dan lebih giat lagi untuk mencapai tujuannya, terlebih dorongan tersebut berasal dari dalam diri mahasiswa yang bersangkutan, sehingga mahasiswa tersebut tidak merasa "terpaksa" 'untuk melakukan aktivitas demi mencapai tujuannya.

Menumbuhkan dorongan dari dalam diri seseorang (memotivasi) ini membutuhkan usaha yang berat dan ketekunan tersendiri. Karena itu, merupakan kelebihan tersendiri bagi mahasiswa yang mempunyai motivasi untuk meningkatkan prestasi belajarnya. Ia akan mampu mengatasi semua kelemahannya, tidak akan mudah menyerah dan mau melakukan apa saja untuk meningkatkan prestasinya

\section{KESIMPULAN}

Motivasi adalah sangat menentukan tingkat berhasil atau gagalnya perbuatan belajar mahasiswa.Belajar tanpa adanya motivasi kiranya akan sangat sulit untuk berhasil. Hal ini disebabkan karena seseorang yang tidak mempunyai motivasi dalam belajar, tidak akan mungkin berhasildi dalam belajarnya. Motivasi merupakan salah satu aspek yang sangat berpengaruh pada diri manusia dalam konteks produktifitas kerja maupun terhadap prestasi seseorang. Seseorang yang memiliki motivasi tinggi akan menunjukkan minat, perhatian, konsentrasi penuh, ketekunan tinggi serta berorientasi kepada prestasi yang diraihnya.

\section{DAFTAR PUSTAKA}

Anwar Dessy. (2003). Kamus Lengkap Bahasa Indonesia Terbaru. Cetakan pertama. Amelia. Surabaya.

Arikunto, Suharsimi (2006). Prosedur Penelitian Suatu Pendekatan Praktek, cetakan ketigabelas. PT Rineka Cipta. Jakarta.

Armstrong, Michael. (2003). Strategic Human ReourceManagement, 
Alih Bahasa Indonesia oleh Ati Cahayati. Manajemen Sumber Daya Manusia Stratejik. PT Gramedia. Jakarta.

Bernardin, H. John and Russell Joyce E.A. (1993). Human Resources Management, McGraw-Hill, Inc, Singapore.
Davis, Keith dan Newstrom, W John. (1996). Perilaku Dalam Organisasi, Alih Bahasa Agus Dharma, SH, M.ED, Edisi ke Tujuh. Penerbit Erlangga. Jakarta. 